\title{
NUT Family Member 1
}

National Cancer Institute

\section{Source}

National Cancer Institute. NUT Family Member 1. NCI Thesaurus. Code C92707.

NUT family member 1 (1132 aa, $120 \mathrm{kDa}$ ) is encoded by the human NUTM1 gene. This protein may be involved in the regulation of testicular function. 